\title{
Managing slope performance in uncertain geological conditions at Meandu Mine, Queensland
}

\author{
J.V. Simmons Sherwood Geotechnical and Research Services, Australia \\ D.C. Edwards Downer EDI Mining Pty Ltd, Australia \\ N. Ferdinands Stanwell Corporation Limited, Australia
}

\begin{abstract}
The Ground Control Management Plan at the Meandu Mine provides the basis for the approval of slope designs and operational activities in a coal deposit sequence characterised by complex sedimentation, thick seams, faults, an eruptive volcanic cover sequence, and multiple episodes of deep weathering. Rapid lateral and vertical variations in geotechnical conditions imply that the overburden model for mine planning includes significant uncertainties for slope hazard and stability risk assessment. The paper provides a description of the evolution of slope designs and circumstances that have shaped the current approach to short-term design and operational hazard management Long-term slope design considerations also include the groundwater regime and the placement of both coal washery tailings and power station ash slurry in mined-out voids.
\end{abstract}

\section{Introduction}

Meandu Mine is located approximately $200 \mathrm{~km}$ from Brisbane and produces thermal coal for the adjacent Stanwell Corporation's Tarong power generation facility - Tarong Power Station (TPS). The coal deposit sequence is characterised by complex Triassic sedimentation with syn- and post-depositional faulting, a complex post-Triassic palaeo-landform associated with deep weathering, Miocene eruptive volcanism, and subsequent Quaternary regolith deposits accompanied by further deep weathering. This setting leads to significant uncertainties for slope hazard and stability risk assessment for mining operations, in particular where deeper seams have been extracted.

The paper gives an outline of geological and geotechnical conditions at the mine, together with a history of the evolution of slope designs and how geotechnical hazard management is applied in largely observational method for the extraction of coal and handling of spoil dumps, and operational hazard management. The paper includes an outline of issues involved with storage of CHPP tailings and power station ash slurry mined-out voids.

\section{Geological setting}

The Tarong Basin (Figure 1) is a small N-S trending basin $60-75 \mathrm{~km}$ long and $15 \mathrm{~km}$ wide which formed during the Late Triassic ( $200-220 \mathrm{Ma}$ ) by dextral strike slip and extensional tectonics (Flood and Garces, 1995; Cranfield et al., 1999). Basin sediments unconformably overlie basement rocks (Figure 2) comprising the Devonian-Carboniferous ( $\sim 360 \mathrm{Ma}$ ) Maronghi Creek Beds to the east and the Late Permian-Triassic ( $250 \mathrm{Ma})$ Boondooma Igneous Complex to the west. Typically coarse-grained sediments inferred to be braided stream deposits (Simmons, 2012) host the Tarong Beds which include the coal measures that are mined at Meandu. The Tarong Beds coal measure sequence consists of thick coal seams which are interlayered with fine grained clay-, quartz-, or iron-rich stone bands of variable thickness within a sedimentary package of conglomerates, sandstones, siltstones and mudstone. 


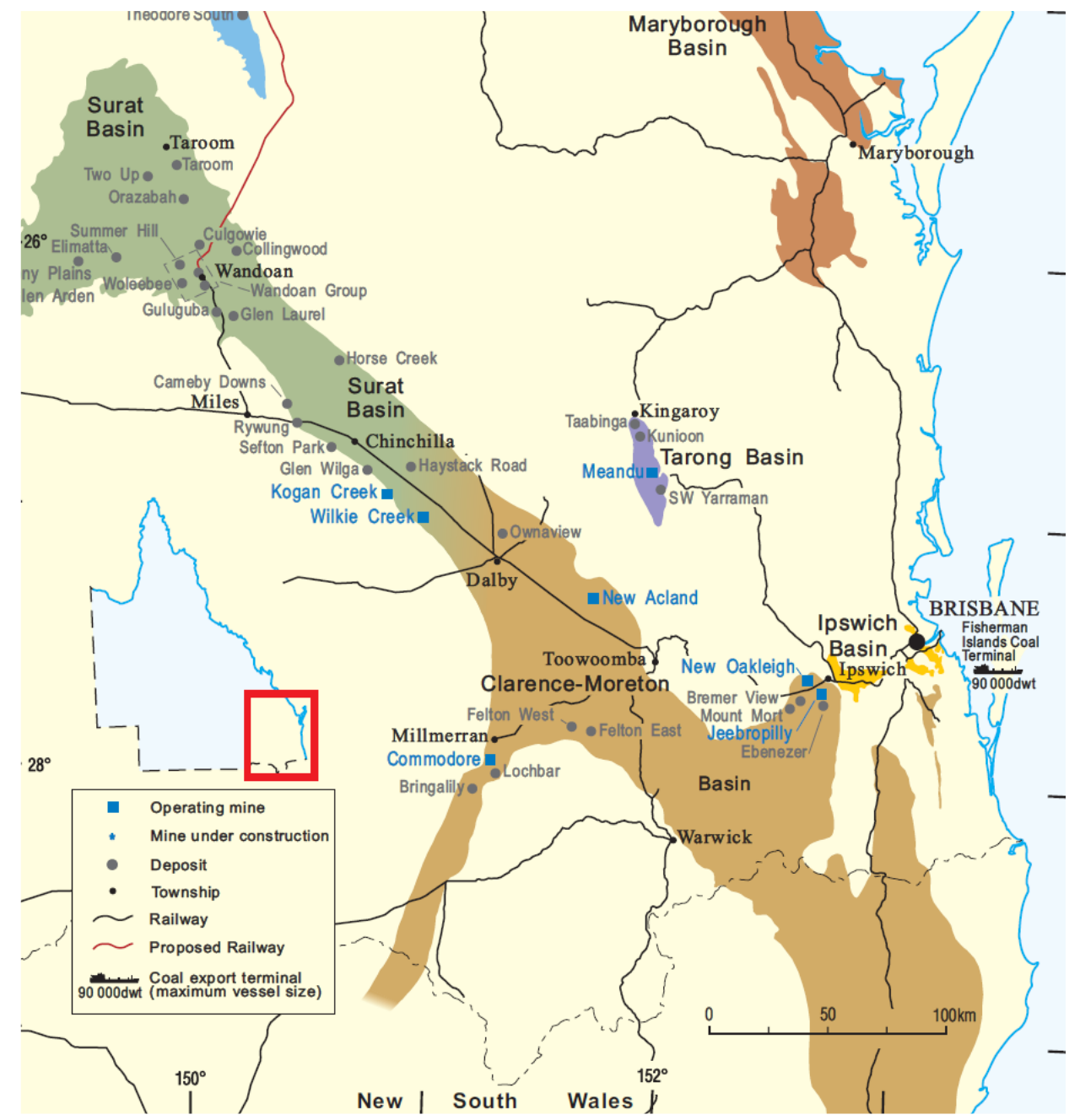

Figure 1 Tarong Basin regional geology (after Queensland Department of Mines and Energy, 2013)

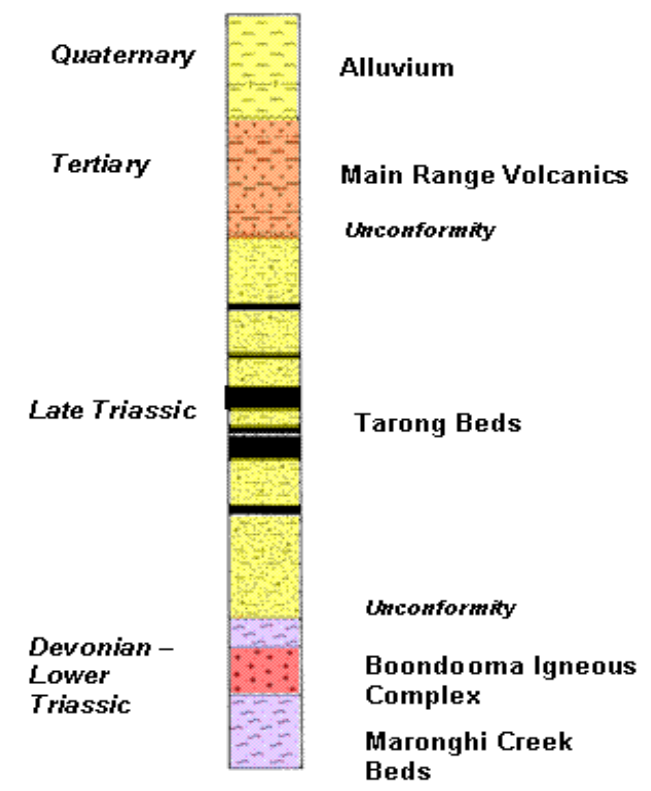

Figure 2 Tarong Basin regional stratigraphic column (after Rodriguez, 2012)

(Note: 'Tertiary' is now Miocene, but both terms remain widely used) 
Pegrem (1995) classified the coal as high ash, low volatile, bituminous, low sulphur steaming coal with weak coking properties. The ash levels within the coal seams increase with stratigraphic depth (Young, 2013). The Tarong Beds also host coal within the Kunioon and Taabinga coal deposits as well as SW Yarraman (Figure 1). Where not exposed at ground surface, the Tarong Beds are unconformably overlain by early Miocene (19.5-25 Ma) aged Main Range Volcanics consisting of thick basalt flows and poorly consolidated lithic sediments. Unconsolidated Quaternary (2.6 Ma-present) cover is present in established watercourses and floodplains. Regoliths comprised of minor ferricretes, red soils, kaolinised and mottled deeply weathered basalts are present within the basin.

Overall geological structure of the coal measures at Meandu comprises mostly $\mathrm{N}-\mathrm{S}$ trending normal faults. Figure 3 shows a typical E-W section through the central part of the mining area, with west-dipping normal faults towards the East and east-dipping normal faults towards the West. Within the middle zone are some grabens and also conjugate sets of shears in zones up to $20 \mathrm{~m}$ wide (Figure 4). Many faults and shear zones also show significant strike-slip displacement (Rolley and Ferdinands, 2012). High-angle reverse faults are rare, and may be caused by reactivated strike-slip of prior normal faults.



Figure 3 Meandu - representative east-west cross section (Rolley and Ferdinands, 2012)

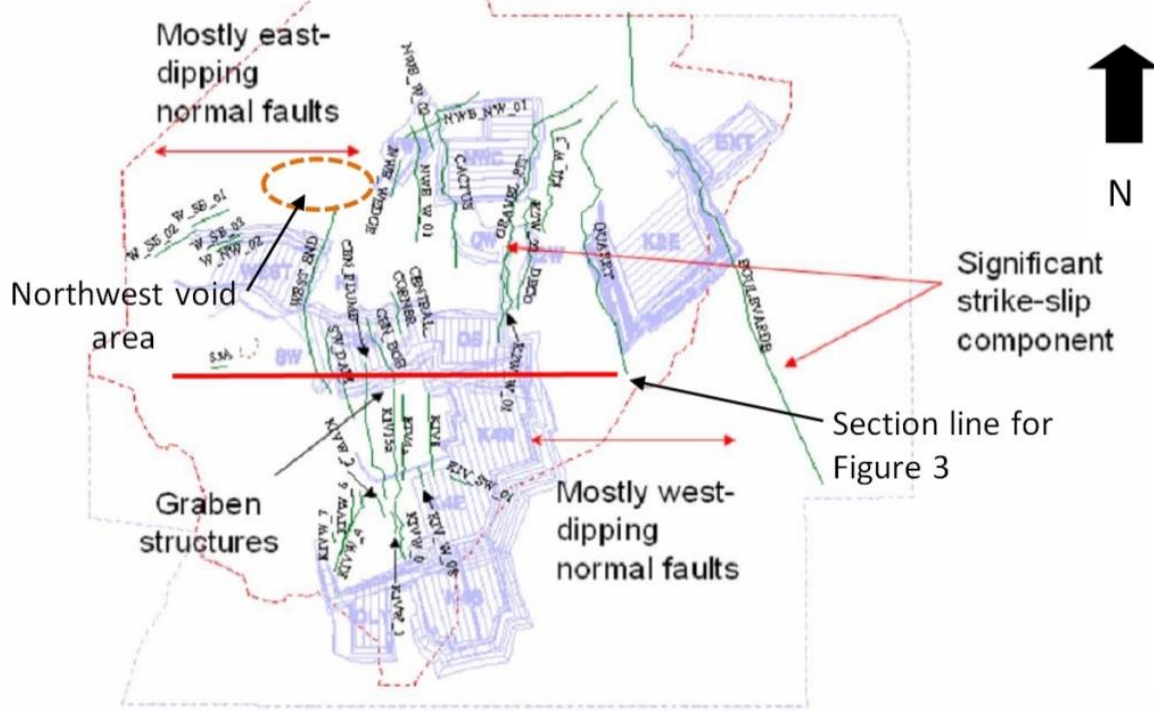

Figure 4 Meandu - overview of faulting domains (from Rolley and Ferdinands, 2012) 
Three basic lithotypes constitute the Tarong coal measures: coal seams, and the sediments above and below King Seam respectively. Other than the contained coal seams, sediments above the King Seam are typically coarse to fine quartzose sandstones with siltstone interbeds and conglomeratic intervals. The relative thickness, frequency of occurrence, and sedimentary structure of the contrasting intervals varies with location as might be expected based on the limited basin dimensions and depositional environment. These sediments have primarily clay cementation with tight contacts. Below the King Seam are typically a wider range of darker-coloured, finer-grained sandstones and siltstones, including carbonaceous siltstones and occasional layers of diamictite characterised by angular feldspathic coarse sands in a carbonaceous siltstone matrix. Claystones are rare, and occasionally present as thin bands within coal partings. Cementation is primarily calcitic or silicious and occasionally sideritic, with siderite also present as clasts or granular bands. Bedding contacts are typically tight, but laminated siltstone-sandstone units tend to be fissile.

The Main Range Volcanics comprise basalt flows and basaltic eruptive deposits, intercalated sediments, and palaeosols that covered a prior land surface with deeply incised valleys and local clifflines. Fresh but highly fractured (jointed) basalts with thicknesses in excess of $90 \mathrm{~m}$ can be juxtaposed with reticulite, ash, weathered and altered sediments, and mass-movement deposits. Some of the late-stage basalt flows are hydrothermally altered to saprolites. The volcanics have been eroded and weathered, including periods of laterisation, and also contain local accumulations of silcrete, kaolinite, diatomaceous earth, and clays of high- to extreme-plasticity.

The Main Range Volcanics are believed to represent a widespread lava field that may have had multiple simultaneous eruptive centres. Geophysical investigations have not been able to identify any eruptive centres within the mine lease area. Igneous dyke and sill intrusions have not been reported.

The basal contact zone of the volcanics comprises typically soil-like materials ranging from stream channel gravels and sands to hillslope colluvium Locally, the contact zone has been observed to include hydrothermally altered granular and clay soils and organics including vegetal debris. The fractured nature of the basalts and relatively permeable reticulite and ash allow infiltration, hydrogeochemical exchanges, and concentration of groundwater flow along the contact zone. Post-Miocene erosion has incised a modern drainage pattern which is not necessarily reflective of the palaeo-topography, while weathering penetration has formed fissured silty clay saprolites particularly within ash and late-phase basalt.

Post-Miocene colluvium and alluvium is typically thin and confined to small-scale drainage channels. For the mine's historical data compatibility purposes all of the cover rocks and sediments are collectively described for geological modelling purposes as 'Tertiary'. Having no economic value, logging of Tertiary materials in geological exploration drillholes was typically minimal until the geotechnical significance of these materials was highlighted by exposure during mining activity over the past decade. While there is now some discrimination of different Tertiary materials in geological models, both the extreme range of geotechnical characteristics and the finer details of the basal contact zone are only approximately defined from exploration.

\section{Geotechnical conditions}

Original (1982-1995) mining plans were concentrated on the sectors of the deposit where the uppermost relatively thick Ace and King seams could be accessed by dragline stripping of primarily Triassic overburden. Many of the early overburden dumps were therefore located directly over lower seams, and distributed widely across several areas demarcated by major faults. From about 1995 onwards, and influenced by significant changes in coal valuation over time, mine plans have been based upon multi-level excavator-truck prestripping and extended-key dragline stripping methods, with a greater proportion of rehandled spoil, Miocene lithologies, and weathered or altered Triassic materials comprising the prestrip component. This geological setting, in combination with operations in several pit areas (Figure 4), therefore provides the primary control over geotechnical conditions, which are further considered below in terms of both excavation and spoil dump development. 


\subsection{Triassic: Tarong coal measures rock mass}

Fresh rock material strengths as measured by point load index and unconfined compressive strength (UCS) tests range from medium to high (Australian Standard AS1726, 1993) above the King Seam, while below the King Seam the predominantly darker and finer, more fissile rocks have somewhat high material strengths Thicker diamictite zones are characterised by high strength and poorly developed joints and are particularly difficult to fragment effectively.

Zones of sometimes complex faulting within the Triassic rock mass delineate, but in some cases, also intersect the major pit areas. Apart from complexities close to fault zones, jointing may be broadly collated into two orthogonal steeply dipping sets (Joints 1 and 2) as demonstrated by stereoplot contours shown in Figure 5. The mean orientations of most mapped faults and shears cluster into two conjugate sets (Fault/Shear 5 and Fault/Shear 6 ) dipping at $30-50^{\circ}$, and the mean strike of these sets coincides with the resolved extensional direction of a NW-trending transtensional event.

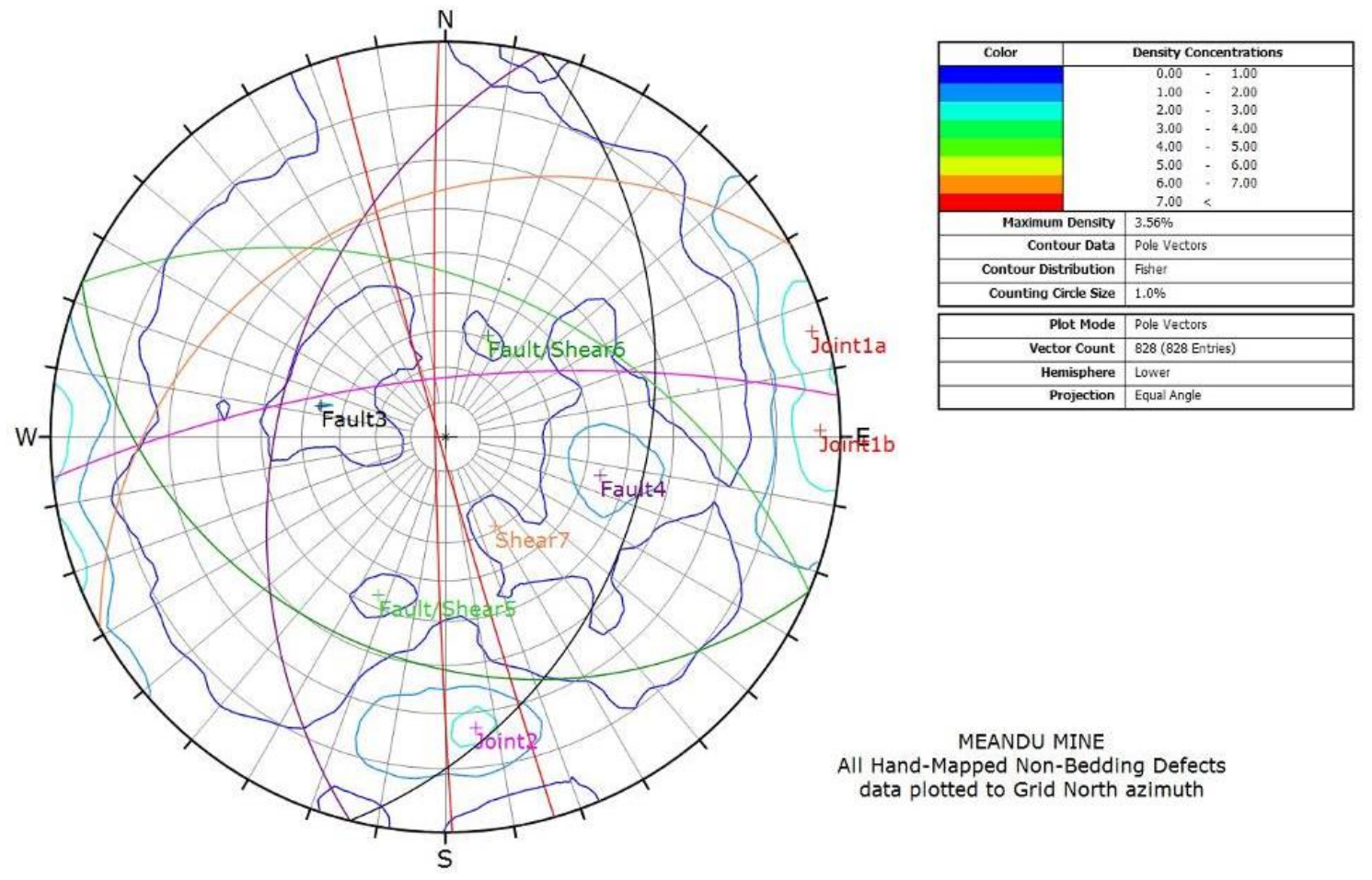

Figure 5 Stereoplot of contoured non-bedding poles for coal measures rock mass showing interpreted principal defect sets

Figure 6 shows an example of a favourably oriented west-dipping normal fault intersection with a $70^{\circ}$ south-dipping presplit highwall. This fault was not identified in exploration or included in modelling due to limitations on the spacing of exploration drillholes and also because the resultant geological model did not display a seam structure anomaly that would trigger fault interpretation. The most problematic structures for wall stability are large curviplanar fractures with continuity and persistence of tens of metres that are encountered in the King Seam to Queen Seam (A-G, Figure 3) interburden. These cannot be identified from exploration drilling but, with the benefit of hindsight, some correlation has been found with locations of apparently abrupt changes in seam dip. 


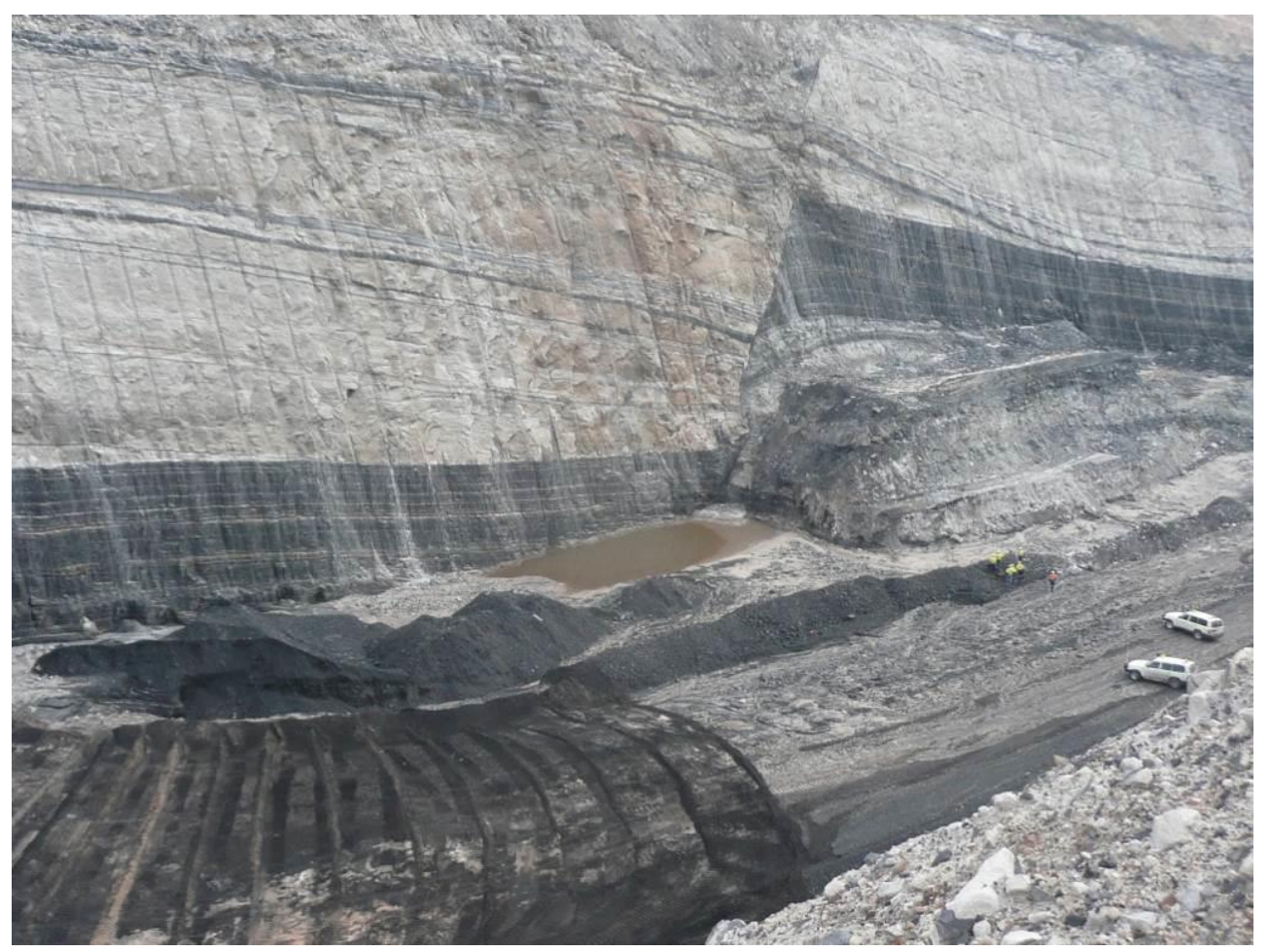

Figure 6 West-dipping normal fault with vertical displacement of $\sim 40 \mathrm{~m}$ (Edwards, 2013)

The thicker coal seams frequently contain syndepositional normal faults and generally low-angle sedimentary injection features which are interpreted as infilled hydraulic fractures and possibly caused by seismicity-induced liquefaction or rapid loading. Face collapse hazards can develop where these features are oriented adverse to the orientation of pit walls. Bedding-parallel shearing is typically confined within fault drag zone width of 5 to $25 \mathrm{~m}$.

The modern base of oxidation represents at least two periods of weathering, pre-dating and post-dating the Miocene volcanism. The weathered interval includes deep leached zones where the strata are relatively permeable and also prone to cratering when blasted. Hazards resulting from cratering include sudden collapse of working surfaces on a scale that can trap both equipment and personnel. Rock mass strengths for both fresh and weathered intervals have been developed in both Mohr-Coulomb and Generalised Hoek-Brown format, based on UCS test data, observations of rock mass blockiness, and back-analyses of both stable and unstable slope profiles.

Contacts within the coal measures rocks have typical frictional strengths of $30^{\circ}$ or higher except at the unconformity with the Miocene materials, as described below. Joints are sometimes cemented with calcite but are only clay-coated and weak where there has been significant oxidation.

Overburden waste materials generated from stripping of fresh Tarong coal measures rocks have typically medium to high strength angular clasts and relatively high shear strength. Saturation-related settlement can result in significant cracking at and behind the crestlines of spoil dumps. Stripping of weathered coarse-grained sandstone generally produces very compressible spoil masses that still exhibit relatively high shear strength despite being prone to saturation-settlement cracking.

\subsection{Tertiary (Miocene): Main Range Volcanics}

The Miocene cover is thickest and most complex in the former valleys, forming a present-day reversed topography with hilltops comprising weathered volcanics (Figure 7). 




Figure 7 Main Range Volcanics overlying weathered to fresh Triassic sediments (Edwards, 2013). Mined-out void is being backfilled with power station ash slurry

Miocene cover rocks are characterised by widespread and often sudden lateral and vertical variability, and exhibit an extreme range of geotechnical and groundwater conditions. Exploration is adequate for broad definition of the Miocene-Triassic contact zone but local orientation details and associated geotechnical hazards, are inevitably discovered during mining with local instability and rockfall hazards in almost every excavated face, irrespective of face orientation.

\subsection{Rehandling of old mine spoil}

Landform rehabilitation has been undertaken progressively since the commencement of mining. Redefinition of economic reserves has required stripping to deeper levels, resulting in rehandling of dumped spoil thicknesses of up to $85 \mathrm{~m}$ by either excavator-truck or dragline methods. The spoil typically comprises granular materials with particle sizes ranging from boulders to sand, mixed with a variable proportion of moist to wet cohesive fines. Temporary stability of vertical cuts as high as $15 \mathrm{~m}$ is attributed to the effects of densification and matric suction. Spoil materials also preserve depositional structure from original dumping, including more permeable accretion surfaces inclined the rill angle and segregated coarser zones at the spoil base. Firm to stiff, slake-prone high plasticity clays form the base of some old spoil profiles where weathered Main Range Volcanics overburden had previously been sidecast, invariably causing face instability during rehandling operations.

Figure 8 shows two examples of excavated faces in old spoil materials. Typical excavator-cut profiles are benched with steep batters, while for dragline pullbacks the slopes are cut and spoil dumped in accordance with the routine dragline low wall design profile. While moist zones are encountered during digging, significant water outflows have only been observed in close proximity to the contact between old spoil and underlying natural ground. 


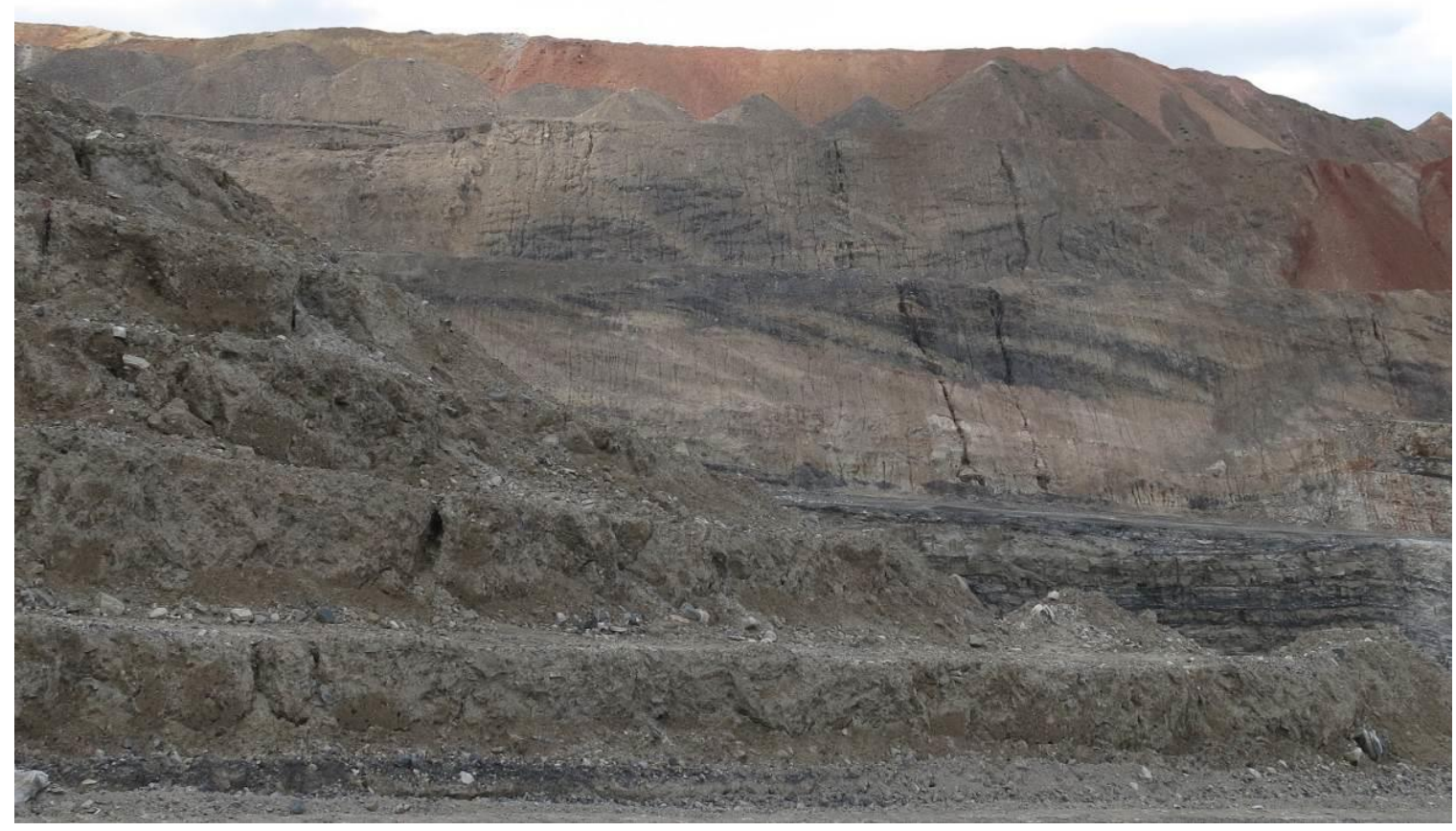

Figure 8 Excavated faces in old spoil (benched material, left fore, $130 \mathrm{~m}$ dragline pullback, rear)

\subsection{Spoil dump development}

Current pit depths exceed $200 \mathrm{~m}$ and the lower component is typically stripped by dragline methods, in some cases with dozer-push assistance. Dragline-generated slope profiles are constructed as steep as possible to overall heights approaching $90 \mathrm{~m}$. Instability has not been experienced at floor dips of up to $15^{\circ}$, except when undercut batters have been oversteepened. Dragline spoil is relatively strong, and design parameters have been based on mining experience and back-analyses. Despite the strengths of the particles and mass, dragline spoil is susceptible to saturation-induced settlement and cracking but this does not lead to slope profile instability.

Truck-dumped spoil is typically placed in lift heights not exceeding $20 \mathrm{~m}$, a limitation imposed by shear strengths obtained from testing of three classes of the weaker weathered spoils sourced from the weathered coal measures rocks and the Main Range Volcanics. Higher lifts have been placed, but only in circumstances where assessments have been carried out based on stability analyses using rill-wedge mechanisms and the Sarma method as outlined in Simmons and McManus (2004). Current overall dump heights well in excess of $200 \mathrm{~m}$ have been constructed by surcharging dragline spoil profiles with multiple lifts of truck-dumped spoil materials (Figure 9).

Groundwater conditions within spoil dumps have not been measured except by monitoring wells installed in rehabilitated dump areas. All observations of spoil slopes and stability back-analysis outcomes are consistent with the widely-held belief that any groundwater within spoil is concentrated within a few metres of the dump floor contact, except for special conditions associated with water ponded in voids. 


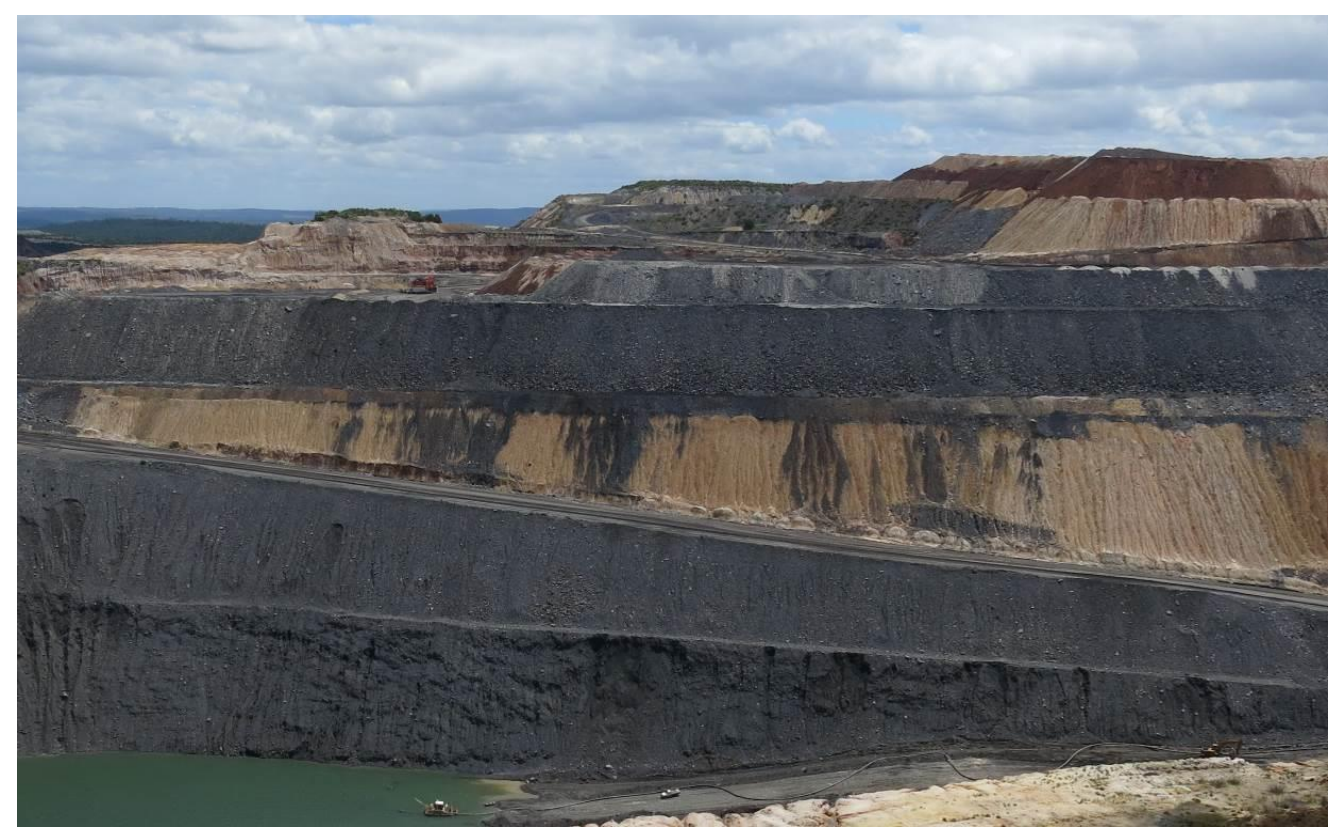

Figure 9 Truck dump surcharging of dragline spoil (low wall ramp formed by dozing of crests)

\section{$4 \quad$ Evolution of pit slope design}

Early mining was concentrated in locations with relatively shallow, typically Miocene-free cover to coal. Dragline sidecast and key-bridge methods were implemented, with excavated batters of $45^{\circ}$ in weathered materials, minimal remnant bench widths, and dumped batters of about $37^{\circ}$. Fresh rock excavations were originally designed at $75^{\circ}$, with presplits for profile heights exceeding $30 \mathrm{~m}$.

Coal seams range in thickness from 5 to $25 \mathrm{~m}$ and typically require blasting prior to excavation, resulting in typically subvertical dig faces controlled by the dominant jointing and cleat development within the coal plies. For design purposes the faces in coal have nominal batters of $80^{\circ}$ and heights may range up to $25 \mathrm{~m}$ depending on the seams and plies being uncovered.

With deeper mining, shovel-truck prestripping capacity was introduced forming rough-cut subvertical dig faces typically 10 to $15 \mathrm{~m}$ high and offset benches to create a nominal $45^{\circ}$ interramp angle. Such benched profile were originally adequate to trap rockfalls from shovel-cut faces in weathered and fresh coal measures rock, but benches often had to be widened where Miocene materials were encountered. The deeper pit wall profiles encountered progressively more complex conditions requiring changes to design profiles based primarily on geotechnical assessment.

\subsection{Slope design and performance for coal measures rock mass units}

As the overall slopes became higher, dragline excavation methods based on dozer-cut extended keys expose the dozer and operator to rockfall hazards which became more frequent where zones of complex faulting are encountered. In response, rock mass defect mapping has been undertaken systematically. Many of the mapping of defects represented in Figure 5 include observations of persistence, continuity, spacing, and surface characteristics. The most frequently observed structures with vertical persistence greater than the average spacing (about $4 \mathrm{~m}$ ) are Joint 1 and Joint 2 . The most common orientations of excavated faces strike roughly $\mathrm{N}-\mathrm{S}$ or $\mathrm{E}-\mathrm{W}$, and in one important case strike ENE-SSW.

For batters of $75^{\circ}$ the mean Joint 1-Joint 2 intersections daylight but this is not the case for batters of $70^{\circ}$. When this design change was introduced, pit by pit as mandated for mitigation of rockfall frequencies, the incidence of rockfall incidents declined dramatically. The other defect sets shown in Figure 5 generally have a negligible influence on slope instability, and this is attributed to their limited persistence or limited occurrence. Adversely-oriented sets (Fault 3, Fault 4, and Fault/Shear 5 and Fault/Shear 6) become more 
continuous and persistent in close proximity to faults or faulted zones. Unfortunately, the continuity and persistence of adversely-oriented structures cannot be interpreted from borehole scanner data alone.

In the King 2 East pit area the Shear 7 structure emerged initially as en-echelon scallop-shaped shears with individual persistences limited to less than $15 \mathrm{~m}$. In three successive strips these shears became linked over distances of $100 \mathrm{~m}$ or more, based on outcrop observations. Tentatively this structural trend has been associated with an apparent hinge-line in the seam structure dip for that area. Operationally, coal recovery has only been achieved with continuous radar monitoring of movements, in combination with temporary buttressing. The presplit batter has also been reduced to $65^{\circ}$ in order to reduce the consequences of instability.

\subsection{Excavated slopes for Main Range Volcanics}

Slope profiles with heights of more than $90 \mathrm{~m}$ are excavated in swelling and fissured hard clays, basaltic extrusive rock ranging from extremely low to extremely high strength, and water charged sands and gravels. The geological model for this range of materials is necessarily over-simplified, as both geometric and parametric variability cannot be adequately captured in exploration data. Slopes are therefore designed on the basis that localised collapse of excavated batters may be inevitable, but that collapsed material volumes should be relatively small and contained on benches. Slope profile design is based on observations of limiting batter heights for stability in three classes of materials described below, taking into account the efficient operating characteristics of equipment:

- 'Free-dig' materials are dug at an interramp angle of $37^{\circ}$, with steep batters and bench heights of 5 to $10 \mathrm{~m}$. In some of the weakest and most water-sensitive materials, typically identified after exposure, overall slope angles have been reduced to $26^{\circ}$ with the benched profile replaced by a continuous dozed slope having a $15 \mathrm{~m}$ catch bench at its toe.

- More competent weathered and fresh rocks are dug at an interramp angle of $45^{\circ}$ with steep batters and bench heights of $10 \mathrm{~m}$. Blasting requirements vary from minimal loosening of very low strength rocks to effective fragmentation of naturally jointed and fissured extremely high strength basalt. Benched profiles in high strength basalt are often difficult to achieve due to the semi-random orientations of joints and fissures. Wherever possible, one or more wider benches carrying haulroads are introduced to provide rockfall control at the base of fractured basalt zones.

- The Miocene-Triassic contact zone is a frequent source of rockfalls and localised batter collapses. Batter collapses are almost inevitable where an irregular steep contact dips into the slope face, effectively forming a thin pillar of generally low strength and inevitably blast-damaged rock. Palaeochannel infill materials are also typically water-charged, marginalising the stability of batter and interramp profiles. Mining methods are modified at potentially adverse channel margins by benching or buttressing to improve stability.

\subsection{Dragline spoil dump profile}

Dragline spoil dumps are typically constructed using cast-blast profiles and in-pit bench methods. Dragline spoil materials are relatively strong and non-slaking, and can normally sustain an undercut (dig) batter of $45^{\circ}$ to a height of $45 \mathrm{~m}$ and a dump batter of about $37^{\circ}$ to a height of $45 \mathrm{~m}$. Minimal remnant bench widths are typically constructed because stability is adequate and the dragline spoil component is maximised.

With current pit depths of $200 \mathrm{~m}$ or greater, dragline spoil dumps are generally surcharged by several lifts of truck-dumped spoil. Stability assessments typically demonstrate that surcharge profile heights in excess of $100 \mathrm{~m}$ can be developed as a single angle-of-repose batter having a toeline within $10 \mathrm{~m}$ of the dragline low wall spoil peak. In practice, the surcharge toeline is kept behind the second spoil peak position in order to utilise the trough behind the first peak for trapping any rocks that may dislodge and roll from the surcharge batter. 
Deep pits have significant catchment areas that contribute runoff water to the pit voids, resulting in substantial ponding depths with correspondingly deep saturation of the dragline spoil base. Despite the strength and slaking resistance of dragline spoils, deep ponding causes saturation-induced settlement with cracking and subsidence of the spoil. Saturation-settlement cracking of low wall haulroads has caused unfounded concerns regarding low wall stability.

\subsection{Excavated slopes for rehandled spoil}

Overall slope angles were originally designed at $45^{\circ}$ based on observation of stable dragline benches, and back-analyses have demonstrated adequate stability provided that most of the exposed spoil mass remains in an unsaturated condition. Rehandle slope profiles are now designed at $45^{\circ}$ for both excavator and dragline pullback operations, with the excavator typically digging single-pass $70^{\circ}$ batters with bench widths adjusted to maintain the overall profile angle. Dragline pullbacks are designed as continuous $45^{\circ}$ batters. Figure 8 shows examples of both types of successful rehandle excavations. Pullback face instability has only been experienced where weak and weathered material at the base of the pullback has become water-saturated. Rockfalls from excavated spoil faces are rare, and benches provide adequate catch capacity.

\subsection{Dumped spoil design and performance}

Several categories of spoil material are recognised. Both fresh coal measures and fresh basalt rocks produce relatively strong spoils. However, the small-scale variability of weathering and/or alteration horizons results in considerable mixing of source materials with wide variations in strength, stiffness, and sensitivity to water.

Dragline-dumped spoil profiles are designed and constructed to the $45 \mathrm{~m}$ height limit of the machine. Truck tiphead heights are normally limited to $20 \mathrm{~m}$, which corresponds to a stable limit assessed based on specific shear strength testing and observations of operational performance. Exceptionally weak or wetter than normal spoil materials are identified during handling and dumped appropriately, either by paddocking with immediate covering and regrading or by limiting tiphead heights to 15 or $10 \mathrm{~m}$.

Large scale and deep-seated spoil dump instability has been rare and experienced only where low-strength and water-sensitive spoil material has been placed at the base of profiles and has subsequently been softened by wetting. Relatively shallow, but high-consequence, spoil face instability has been more frequently experienced following episodes of heavy rainfall with significant and concentrated surface water runoff. Inevitable dump crest settlement is uneven, leading to depressions and ponding against windrows which then causes softening, settlement, and sinkhole development. Wet weather access restrictions can thus contribute to unmanaged water infiltration that rapidly progresses to the base and face of the dump profile.

Single-lift dumped spoil faces are susceptible to rill-wedge instability (Simmons and McManus, 2004) under such circumstances. If instability develops during a rainfall event, runoff erodes the unstable area. In recent years the combination of a higher proportion of weak and water-sensitive, Miocene-sourced prestrip spoil and severe rainfall events has resulted in settlement cracking, sinkhole development, and localised erosion gullying or rill-wedge instability in several dump locations. It is operationally difficult to maintain effective grading and drainage in non-active areas to minimise the impacts of heavy rainfall events. In addition, even in active dumping areas the range of spoil materials placed at any dump location can be highly variable because of the lateral and vertical variability of source geological conditions. Effective dump management has relied on regular inspections, grading, and implementation of a partial short-dumping procedure for soft tipheads.

\section{$5 \quad$ Geotechnical hazard management}

The mine's Ground Control Management Plan describes the hazard management actions ranging from approval and risk rating of designs to operational activities including hazard identification, risk assessment, 
control implementation, safe operating procedures, and a range of monitoring actions. Regular visual inspections of all slopes are supplemented by situation-specific movement measurements involving a combination of tell-tales, extensometers, prism survey, and radar.

Statutory open cut examiner inspections are backed by regular and on-request inspections by the site geologist and mining supervisors. Trigger action response levels are formally set using observation-based checklists, but responses can also be triggered by simple observations at any time and location. Where required, task-specific risk assessments and response plans are developed. Regular and situation-specific inspections are also carried out by visiting geotechnical specialists, and formal responses are required to any recommendations that are included in specialist reports.



Figure 10 Local area radar monitoring for a work area below a fractured highwall face

In 2013 the mine acquired dedicated radar movement monitoring facilities. Prior to this, radar had been leased for specific requirements. Site personnel therefore had experience and confidence in radar deployment as a supplement to observation-based responses. A trailer based system is used for wide area coverage while a light vehicle based system can be deployed for providing the fastest possible scan repeatability for work areas exposed to potentially rapid-onset, brittle face instability. Figure 10 shows the work area radar providing local wall movement warning to a blast loading crew. Effective radar deployment is challenged when radar units are located on spoil dumps in order to observe excavated rock faces. Techniques have been developed to measure the movements of radar locations on dumps and thereby rescale the scans and apparent displacements measured.

\section{Storage of coal processing waste and power station ash}

Management of geotechnical hazards applies to all pit slopes including mined-out voids which are backfilled with coal handling and preparation plant (CHPP) waste and power station ash slurries. 


\subsection{Coal processing waste: rejects and tailings}

The CHPP produces a consistent product coal that is conveyed to the neighbouring Tarong power stations (TPS) complex, and generates two rejects streams comprising coarse carbonaceous sandy gravel and fine sandy and clayey silt tailings slurry. Coarse rejects is stockpiled for truck transport to dump areas which are covered by suitable overburden spoil and topsoil for final rehabilitation. After drying-back, this material is much stronger than almost all of the typical spoil materials. When fresh and wet, however, it must be handled carefully to avoid dump-point instability.

Coarse rejects has been successfully placed in layers not less than $5 \mathrm{~m}$ and not greater than $8 \mathrm{~m}$ for low-stress covering of extremely low strength tailings. Under such conditions the cover typically cracks due to initial undrained shear displacement in combination with relatively rapid consolidation of the tailings. Initial covers of this nature have subsequently provided stable platforms for incremental coverage of 10 to $20 \mathrm{~m}$ lifts of truck-dumped coarse rejects or overburden spoil.

The first tailings storage structure at the site was a purpose-built dam. Subsequently tailings slurry has been pumped to mined-out voids. These storages also function to provide reclaim water for dust suppression and CHPP re-use. Capping of one such storage, the northwest void (Figure 4), has been effectively completed. Similar tailings facilities will be used for the remainder of the mine life.

Two methods were used for capping the northwest void: low-level rejects placement and high-level spoil placement. Where approximately $30 \%$ of the perimeter was bounded by a rejects dump, a low-level $5 \mathrm{~m}$ initial cover was applied using rejects. The tailings margin was demarcated by alignment posts to prevent truck trafficking, with the cover advanced as concave face using dozers. Cracked areas were left to consolidate for as long as possible. Observations of crack locations and movement rates controlled the advance of a second $5 \mathrm{~m}$ cover no closer than $50 \mathrm{~m}$ to the initial cover edge. Trucks could operate where the second layer was not cracked. Subsequent layers of $10 \mathrm{~m}$ and then $20 \mathrm{~m}$ of coarse rejects or mine spoil were then advanced using a high-level dumping procedure.

Where the remaining $70 \%$ of the perimeter was bounded excavated walls and spoil dumps, a high-level dumping procedure was used to avoid loaded trucks having to haul downhill. This caused some displacement of the crusted tailings, and truck access was again restricted to the limits of cracking and crest subsidence. To maintain 'steady-state' displacement of the tailings, the tiphead height was maintained at $30 \mathrm{~m}$ and commenced from existing dumped spoil. The high spoil face was formed in a concave shape, and gradually extended around the remaining excavated wall perimeter. After as much as $400 \mathrm{~m}$ of advance the two cover methods linked-up, and the high-face method with spoil dumping was reduced to firstly $20 \mathrm{~m}$, and for the last closure dozed-out to a minimum of $5 \mathrm{~m}$.

\subsection{Power station ash}

TPS generates two waste streams from coal combustion. Bottom- or furnace-ash is a gravelly sand reclaimed from boilers and stored separately. Initially a large purpose-built dam was used to store sandy silt fly ash slurry. Following effective filling of this dam, ash slurry has been pumped about $5 \mathrm{~km}$ to the mined-out void shown in Figure 7. Environmental management conditions associated with the ash storage include demonstration of acceptable groundwater standards. Networked wells monitor seepage outflows based on the extent and elevation of the low-permeability rock rim underlying the spoil. Consolidation of the beached ash storage is maximised by recycling supernatant water. Storage design included stability assessments for all stages of filling and capping, mitigation measures for potential pipeline breaches along the pipeline corridor across a rehabilitated spoil dump, and appropriate spillways for control of storm runoff from the storage catchment.

\section{$7 \quad$ Conclusions}

At Meandu Mine many geological, geotechnical, and climatic factors combine to create mining conditions requiring continuous experienced-based review of hazards and associated risk management. The larger 
scale structural setting of the deposit is well-defined, but large lateral and vertical changes occur over small distances where infill drilling is not practical.

Pit slope designs are based on precedent experience, back-analysis, and specific stability assessment, allowing for the practical aspects of machine positioning and exposure of personnel. Excavated slopes are designed as steep as possible, with modifications as mining has progressed into the more geotechnically challenging sectors of the deposit. Geological complexity, weak and weathered contacts, and heavy rainfall events, all require risk mitigation by controlling instability consequences.

Rehandling of old spoil material has been straightforward, but maintenance of dump crest stability involving weak water-sensitive materials requires periodic re-treatment. Deep tailings deposits have been successfully capped using combinations of cover methods as judged appropriate for specific risk profiles. Storage of power station ash slurry has required ongoing monitoring of slope stability, seepage conditions, and groundwater quality, based upon geotechnical assessment of all stages from deposition to final cover and land surface rehabilitation.

\section{Acknowledgement}

The authors acknowledge the permission of Stanwell Corporation Limited as mine owner and Downer EDI Mining Pty Ltd as mine operator to publish this information regarding Meandu Mine. Current site knowledge is also based on the experiences of the previous mine operator (Thiess Pty Ltd, 2008 to 2012), and previous owner/operator (Pacific Coal Pty Ltd, 1982 to 2007). Contributions of many individuals, over a time-period in excess of 30 years, are acknowledged with thanks. Notwithstanding, any opinions or judgements expressed remain the responsibility of the authors.

\section{References}

Australian Standard AS1726 (1993) Geotechnical Site Investigations, Standards Australia, Sydney.

Cranfield, L.C., Randall, R.E. and Pascoe, G.S. (1999) Kingaroy 1:100,000 Geology Map Sheet, Department of Mines and Energy, Queensland, Australia.

Edwards, D.C. (2013) An Introduction to Meandu Mine Geology, Unpublished Internal Training Document, Downer EDI Mining Pty Ltd, Meandu Mine, Nobby Smith Way, Nanango Queensland, Australia, 4615, 15 p.

Flood, P.G. and Garces, B. Jr. (1995) The Tarong Basin, Queensland: a Late Triassic strike-slip (pull-apart) basin containing alluvial fan and coal-rich fluviatile sediments, C.R. Ward, H.J. Harrington, C.W. Mallett and J.W. Beeston (eds), Geology of Australian Coal Basins, Geological Society of Australia Coal Geology Group Special Publication.

Pegrem, B.J. (1995) Tarong Basin, C.R. Ward, H.J. Harrington, C.W. Mallett and J.W. and Beeston (eds), Geology of Australian Coal Basins, Geological Society of Australia Coal Geology Group Special Publication, Vol. 1, pp. 465- 470.

Queensland Department of Mines and Energy Map (2013), viewed 30 April 2013, http://mines.industry.qld.gov.au/assets/coalpdf/se_qld_coal_map_10.pdf.

Rolley, C. and Ferdinands, N. (2012) Meandu Geology, Unpublished presentation for the Bowen Basin Geologist's Group, Stanwell Corporation, Meandu Mine, Nobby Smith Way, Nanango Queensland, Australia, 4615, 38 p.

Rodriguez, S. (2012) Tarong Coal Project, Meandu Mine, Unpublished presentation for the Bowen Basin Geologist's Group, Thiess Pty Ltd, Meandu Mine, Nobby Smith Way, Nanango Queensland, Australia, 4615, $20 \mathrm{p}$.

Simmons, J.V. (2012) Meandu Mine: Geotechnical Home of the Friends of the Tertiary, Unpublished presentation for the Bowen Basin Geologist's Group, Sherwood Geotechnical and Research Services, Australia, 18 p.

Simmons, J.V. and McManus, D.A. (2004) Shear strength framework for design of dumped spoil slopes for open pit coal mines, in Proceedings Advances in Geotechnical Engineering: The Skempton Conference, R.J. Jardine, D.M. Potts and K.G. Higgins (eds), 29-31 March 2004, London, UK, Thomas Telford Limited, Vol. 2, pp. 981-991.

Young, J.L. (2013) Meandu Mea_13_02 Model Report, Unpublished Internal Resource Report by JB Mining Services for Stanwell Corporation Pty Ltd. 